\title{
Violence Against Drivers and Conductors in the Road Passenger Transport Sector in Maputo, Mozambique
}

\author{
Maria Tereza Couto a, $b^{\star}$ MD, FCS(ECSA)1 \\ ${ }^{a}$ Department of Public Health Sciences, Karolinska Institute, Stockholm/Sweden \\ ${ }^{b}$ Faculty of Medicine, Eduardo Mondlane University, Maputo/Mozambique \\ Stephen Lawoko a MSC., PhD \\ ${ }^{a}$ Department of Public Health Sciences, Karolinska Institute, Stockholm/Sweden \\ Leif Svanström a BA, MD, PhD \\ a Department of Public Health Sciences, Karolinska Institute, Stockholm/Sweden
}

\section{ABSTRACT}

This cross-sectional study examined the extent, nature and risk factors of workplace violence in the road passenger transport sector in Maputo, the capital city of Mozambique. A random sample of 504 participants was selected from a population of 2618 registered bus, minibus, and taxi drivers/conductors. The results indicated that workplace violence, psychological as well as physical, is highly prevalent among drivers/conductors, with 77\% reporting ever being abused and $64 \%$ reporting being abused during the past 12 months. Particularly vulnerable groups comprised illiterate employees, bus drivers/conductors, employees with long experience, and those holding a supervisory position. In addition, a high workload was associated with an increased likelihood of exposure to workplace violence in the road passenger transport sector. This article discusses the implications of the findings for possible interventions and further research.

\section{INTRODUCTION}

Workplace violence is an alarming phenomenon world-wide. A large European survey covering 31 countries and different work sectors placed the yearly prevalence of physical abuse in the workplace at $5 \%$, sexual harassment at $2 \%$, and bullying/harassment at $5 \%$ (European Foundation for the Improvement of Living and Working Conditions, 2007). Of

1 Correspondence to:Maria Tereza Couto Department of Public Health Sciences, Division of Social Medicine, Norrbacka 2nd floor, 17176 Stockholm/Sweden E-mail: maria.couto@ki.se or couto@tdm.co.mz 
the 4.5 million crimes of violence reported in the United States of America (USA), including assault, rape, sexual harassment and robbery, $16.3 \%$ were a result of violence directed towards employees while on duty (BJS, 2006).

An overwhelming majority of the studies on workplace violence have focussed on the healthcare sector. In this sector, prevalence studies have suggested that violence is common with little geographical variation. In the USA, for example, a prevalence of 8-38\% has been reported in contrast with 15-39\% in South America; 10-73\% in Asia; 9-56\% in the Middle East; $10-67 \%$ in Australia; and 4-52\% in Africa (Carmi-Iluz, Peleg, Freud, \& Shvartzman, 2005; Di Martino, 2002, 2003; Jackson \& Ashley, 2005; Kasara, Pathrapon, \& Bungorn, 2003; Kowalenko, Walters, Khare, \& Compton, with the Michigan College of Emergency Physicians Workplace Violence Task Force, 2005; Kwok et al., 2006; Palacios et al., 2003; Steinman, 2003; Eduardo Mondlane University, 2003).

Workplace violence accounts for significant work-related mortality. In the USA, workplace homicide is the fourth leading cause of work-related death. In addition to homicides and injuries, workplace violence can lead to depression, anxiety, stress, psychosomatic complaints, helplessness and burnout (Arnetz \& Arnetz, 2001; BLS, 2007; Chappell \& Di Martino, 2006; Di Martino, 2003; Lanza, Zeiss, \& Rierdan, 2006; Lundström, Saveman, Eissemann, \& Astöm, 2007; Menckel \& Viitasara, 2002; Soares, Lawoko, \& Nolan, 2000; Winstanley \& Whittington, 2002; NIOSH, 2007).

A myriad studies, particularly within the healthcare sector, have attempted to investigate those factors that may contribute to workplace violence. Workplace violence has been placed in a framework suggesting that the interaction between victim/perpetrator characteristics and work environmental factors increases/decreases employees' vulnerability to abuse (Chappell \& Di Martino, 2006). Individual characteristics, such as age, gender and occupational experience, have previously been implicated as risk factors of workplace violence. For example, being of a young age, female, a nurse, and lacking work experience have been associated with increased vulnerability to workplace violence in the healthcare sector (Arnetz, Arnetz, \& Petterson, 1996; Chappell \& Di Martino, 2006; Fazzone, Barloon, MacConnell, \& Chitty, 2000; Lee, Gerberich, Waller, Anderson, \& MacGovern, 1999; Menckel \& Viitasara, 2002; Lawoko, Soares, \& Nolan, 2004; Soares et al., 2000). Moreover, employees' poor health conditions have been associated with increased vulnerability to abuse (Arnetz et al., 1996; Menckel \& Viitasara, 2002). Exposure to violence may vary depending on conditions under which employees work, and in which occupational category, among other things (Chappell \& Di Martino, 2006). Workplace characteristics, such as form of employment (full time working); type of care setting (e.g. psychiatric care, emergency department); working hours (evening and nights); working alone; working in public environments; high workload; and organisational changes (e.g. downsizing) are factors that may increase exposure to and risk of workplace violence (Arnetz \& Arnetz, 2001; Chappell 
\& Di Martino, 2006; Kwok et al., 2006; Lawoko et al., 2004; Mayhew, 2000; Nolan, Soares, Dallender, Thomsen, \& Arnetz, 2001; Soares et al., 2000; Viitasara, Sverke, \& Menckel, 2003).

Despite growing evidence of workplace violence in the healthcare sector and increased knowledge regarding its risk factor and health consequences, studies from other sectors are comparatively scarce. Particularly, far less attention has been given to investigating violence in the transport, commerce, education, postal and telecommunication, hotels, public services, media and entertainment industries, catering and tourism sectors. This article scrutinises workplace violence in the road passenger transport sector. There is reason to suspect that the profile of abuse (e.g. nature, extent and risk factors) may be of a unique character. Unlike healthcare settings, where relationships between patients and care personnel can be established, the transport sector is characterised by a unique form of interaction. The work of drivers and conductors involves interaction with strangers on a daily basis. It is, therefore, a challenge to understand the extent, nature and risk factors of violence in this unique sector.

\section{WORKPLACE VIOLENCE IN THE TRANSPORT SECTOR}

The transport sector comprises air, railway, maritime and road transport. Employees in the road passenger transport sector are at potential risk of exposure to workplace violence as they meet a diversity of clients, including potential perpetrators (e.g. alcohol and drug abusers). Moreover, factors, such as delays in transportation; poor information following delays; the quality of environmental surroundings; and failure to meet passenger expectations, are likely to incite anger and frustration in the public, and increase the risk of aggression (Boyd, 2002; Chappell \& Di Martino, 2006; Essenberg, 2003). Thus, violence against employees in the road passenger transport sector is usually triggered externally (e.g. violence occurring between an employee and any other person present at the workplace). There have, however, been reports of internally induced acts of violence involving employees and their managers and supervisors (Chappell \& Di Martino, 2006; Essenberg, 2003; ILO, 2004). In addition, workers in the road passenger transport sector in several countries have complained of harassment and extortion by members of the armed forces, police officials, and customs agents at road blocks or border posts (Essenberg, 2003).

Violence in the road passenger transport sector is common. Reports from the developed countries have indicated that between $19-70 \%$ of taxi drivers have been subjected to abuse ranging from verbal to physical (Elzinga, 1996; Mayhew, 2000; Richardson \& Windau, 2003). This violence is often associated with factors, such as working alone; working at night; availability of cash; and working in high crime areas (Castillo \& Jenkins, 1994; Chappell \& Di Martino, 2006; Elzinga, 1996; Essenberg, 2003; Jenkins, 1996; Mayhew, 
2000; Richardson \& Windau, 2003). Among bus drivers, interaction with members of the general public who have been drinking; public frustration at having to wait; and fare evasion, put drivers at a heightened risk of abuse (Chappell \& Di Martino, 2006; Essenberg, 2003).

In African countries there is lack of studies of workplace violence in the road passenger transport sector. In this study, workplace violence in the road passenger transport sector in Maputo has been scrutinised for the first time. More specifically, the study analysed the prevalence and nature of workplace violence against drivers and conductors and identified the individual and work-related risk factors associated with workplace violence in the road passenger transport sector in Maputo.

\section{WORKPLACE VIOLENCE IN MOZAMBIQUE}

Mozambique is located in South-Eastern Africa and has about 20530714 inhabitants (INE, 2007). The capital city of the country is Maputo. With an infant mortality rate of 107.9/1,000 births, a life expectancy at birth of 42.3 years, a total adult literacy rate of $46.4 \%$ (INE, 2005) and a GDP per capita of 197.4 USD (INE, 2002), Mozambique remains a developing country. As a consequence of almost two decades of armed conflict (1976-92), there is an apparent culture of violence in the country (Boothby, 1992). A study of mortality due to injuries in Maputo indicated that homicides accounted for about $20 \%$ of all injury mortalities (Nizamo, Meyrowitsch, Zacarias, \& Konradsen, 2006). Concerning workplace violence, only one study has been published to date. The study investigated violence among healthcare professionals where a prevalence of workplace violence of over $40 \%$ was reported (Eduardo Mondlane University, 2003).

To date, no study has been undertaken to investigate violence in the transport sector in Mozambique. This study sought to investigate the extent, nature and risk factors of workplace violence in the road passenger transport sector in Maputo.

\section{METHODS}

\section{DEFINITIONS}

Workplace violence is defined as behaviour by an individual/individuals, within or outside an organisation, that is intended to physically and/or psychologically harm a worker/workers and occurs in a work-related context (Schat \& Kelloway, 2005). In this study, the operational definition of workplace violence is: threatening or aggressive behaviour (verbal); spitting, scratching or pinching; use of physical force, such as punching, slapping and kicking; physical threat involving no actual physical violence; sexual harassment; and use of an object or a weapon against the employee. Thus, a victim of workplace violence is a driver or conductor who is subjected to one, several, or all of these abusive behaviours. 
Work environment can be measured in terms of demand, control and support at work.

- Demand is classified under psychological and physical demand. Psychological work demand or workload is defined as stressors present in the work environment (e.g. high working pace, high pressure time, difficult and mentally exacting time); and physical work demand or workload is defined as efforts done at work (e.g. high efforts carrying heavy objects) (Karasek, 1979; Karasek \& Theorell, 1990).

- Control constitutes the worker's ability to control his/her own activities and skill development (Karasek, 1979; Karasek \& Theorell, 1990).

- Support is defined in terms of support received, such as emotional and instrumental support, cognitive guidance, social reinforcement, informative and appraisal support (Hirsch, 1980; House, 1985; Norbeck, Lindsey, \& Carrieri, 1981).

The operationalisation of these concepts in the current study is presented under the "Measures" section below.

\section{SETTINGS AND PARTICIPANTS}

The research was conducted in the road passenger transport sector in Maputo. The city occupies $300 \mathrm{~km}^{2}$ of land, with a population of 1099102 inhabitants (INE, 2007). Road passenger transport is provided by buses, minibuses and taxis belonging to one government bus company and two transport associations, namely, a bus and a taxi association. The total population of registered drivers and conductors in the city is 2618 with the following distribution: 405 bus drivers; 377 bus conductors; 743 mini-bus drivers; 743 minibus conductors; and 350 taxi drivers. There are no taxi conductors.

A pilot study was first conducted (among 50 participants) to determine, among other things, the probability of workplace violence, in order to determine the required sample size for this study. The pilot study also investigated the cultural acceptability and validity of instruments to be used. The results of the pilot study indicated a prevalence of workplace violence of about $74 \%$. Based on these results, a power analysis was performed and a sample size of 504 participants was considered adequate to ensure a power of over $80 \%$. The participants were randomly selected from each stratum to ascertain representation: 144 minibus drivers;144 minibus conductors; 72 bus drivers; 72 bus conductors; and 72 taxidrivers.

\section{THE EMPLOYMENT CONTEXT OF DRIVERS/CONDUCTORS IN MAPUTO}

Drivers and conductors perform multiple duties. Conductors are expected to assist drivers in collecting fares from passengers and see to it that there is harmony among passengers. In addition, both drivers and conductors assist in loading passengers' belongings and perform several duties to ensure safety and hygiene in the vehicle. These include cleaning the vehicle; checking for mechanical problems; fixing punctures; and repairing any damage 
that may occur to the vehicle. A driver or conductor can also hold a supervisory position. The supervisors are expected to resolve internal (between employees) and external (between employee and passenger) conflicts. They also check whether all vehicles have a valid licence; inspect whether vehicles have undergone the yearly service; and ensure that vehicles follow the order of arrival at the stations (e.g. taxi stops and bus/minibus terminals). Amidst high competition for passengers, the multiple duties of drivers and conductors imply that they have to work fast and intensively. Also, these multiple roles could imply that employees in this sector may be faced with conflicting job demands (e.g. conductors and drivers may not have prior knowledge of mechanical work; and supervisors may not have prior training in conflict resolution).

\section{DESIGN AND PROCEDURE}

The study design was cross-sectional. The questionnaire was translated into Portuguese, the official language of the country. The questionnaire covered socio-demographic characteristics; access to information; literacy level; occupational experience; organisational changes; work environment; work conditions; health conditions; quality of life; life style; workplace violence reactions; consequences; and burnout. For the current article, questions concerning workplace violence; occupational experience; organisational changes; work conditions; work environment; socio-demographic characteristics; literacy level; and access to information were of primary interest.

Data was collected during eight consecutive weeks by three trained interviewers. The interviewers' training package included understanding the study aims, the questionnaire content and administration; understanding ethical issues, such as respect for privacy while performing the interviews; as well confidentiality and emphasis on voluntary participation. Participants were contacted at their workplaces or homes, and in some cases, appointments were made telephonically. Addresses/telephone numbers were obtained from government administrators, bus companies, bus/taxi transport associations and the National Traffic Institute. The participants had already been informed of the pending study by their respective associations. The National Committee of Bioethics for Health in Mozambique approved the study.

\section{MEASURES}

Workplace violence, occupational experience, organisational changes, and work conditions were assessed using a previously validated questionnaire widely used in developed countries (Arnetz, 1998; Arnetz \& Arnetz, 2000). Following the pilot study, the questionnaire was adapted to reflect the road passenger transport sector.

\section{DEPENDENT VARIABLE}

Workplace violence was assessed using questions probing whether participants had ever, or during the past 12 months, experienced verbal threat/aggression; been bitten, slapped, hit, 
pushed, spat at, scratched, pinched, punched or kicked; or faced any unpleasant experience at work. "Unpleasant experience" essentially reflects the victim's individual perception of the incident, rather than describing the nature of the violent behaviour (Arnetz, 1998). The response alternatives were "No", "Yes, once or twice", or "Yes, several times".

Other questions probed the perpetrator (e.g. passenger, co-worker, owner of vehicle); place of occurrence (e.g. at bus/taxi stop, while driving, inside of vehicle); time of occurrence; and whether an object (e.g. knife, gun) was used.

\section{INDEPENDENT VARIABLE}

Occupational experience was accessed using questions regarding participants' number of years working in the road passenger transport sector; number of years working at their present workplace; and whether participants held a supervisory position.

Organisational change was assessed by inquiring whether there had been any recent organisational changes at the workplace. Possible responses were "Yes", "No", or "Don't know".

Work conditions and Work environment were assessed using the Swedish DemandControl-Support Questionnaire (DCQ) (Johnson \& Hall, 1988; Johnson, Hall, \& Theorell; 1989; Karasek, 1979; Karasek \& Theorell, 1990), which assesses work-related demands, control and support.

Demand was assessed with five questions probing intensity and speed of work; efforts devoted to work; availability of time to accomplish work; and conflicting demands. The Cronbach's alpha test for reliability for this scale was 0.45 .

- Control was assessed with six questions probing whether work offered the possibility for further learning; demanded high skill; offered the possibility for initiative taking; varied in nature; and offered the possibility for choices. The Cronbach's alpha test for reliability for this scale was 0.54 . The items for demand and control were scored on a $1-4$-point scale (often $=4$, sometimes $=3$, seldom $=2$, never/almost never $=1$ ).

- Support was assessed by asking participants to take a position on six statements regarding, among other things, whether the environment was calm, pleasant and enjoyable, as well as support and understanding from colleagues. The responses were scored on a 1-4-point scale (strongly agree $=4$, mildly agree $=3$, mildly disagree $=2$, strongly disagree $=1$ ). The Cronbach's alpha test for reliability for this scale was 0.84 .

Individual scores on the three subscales (i.e. demand, control and support) are calculated by summing respective items in each subscale. The resulting sum is a continuous scale. 
The higher the score, the higher the work demand, control and support respectively.

Socio-demographic characteristics were assessed using indicators, such as age, marital status, highest educational achievement and occupation. As this sector rarely attracts female workers in Mozambique, all participants were male.

Access to information was assessed by probing whether participants had access to radio/ TV or newspapers. Possible responses were "Yes" or "No".

Literacy level was assessed by asking participants whether they could read or not.

These variables were treated as the independent variables in the analyses.

\section{STATISTICAL ANALYSIS}

SPSS for windows version 15.0 software package was used for all analyses. Chi-square tests were used to assess associations between the dependent variable (exposure to violence) and categorical independent variables. A $t$-test was used to study the association between the dependent variable and continuous independent variables. Logistic regression was used to assess the independent role of demographic indicators; access to information; literacy level; occupational factors; and work environmental factors in explaining exposure to violence. Statistical significance was assumed at a $p$-value $<0.05$.

\section{RESULTS}

\section{PREVALENCE AND NATURE OF WORKPLACE VIOLENCE IN THE ROAD PASSENGER TRANSPORT SECTOR}

As shown in Table 1 below, a significant proportion of participants (77.4\%) reported having experienced workplace violence in their life time, and (64.3\%) during the past 12 months. Verbal abuse/Aggression (47.0\%), unpleasant experiences (20.8\%) and pushing (20.0\%) were the most frequent types of violence. About $17 \%$ of participants had been physically assaulted with objects, including guns, stones, bottles and sticks. Passengers (51.6\%), co-worker conductor (18.1\%) and owner of vehicle $(11.3 \%)$ were the most common perpetrators. Violence occurred most frequently at a bus stop (45.6\%); while the vehicle was in motion (22.4\%); and most often in the morning (43.1\%).

Table 1. Workplace violence: Prevalence, type of violence, use of object, perpetrator, place and time of occurrence

\begin{tabular}{|l|c|c|}
\hline \multicolumn{1}{|c|}{ Variable } & Total Number & Proportion (\%) \\
\hline \multicolumn{1}{|c|}{ Prevalence in life time } & & \\
\hline No, never & 114 & 22.6 \\
\hline Yes, once or twice & 247 & 49.0 \\
\hline
\end{tabular}




\begin{tabular}{|c|c|c|}
\hline Yes, several times & 143 & 28.4 \\
\hline \multicolumn{3}{|c|}{ Prevalence during the past 12 months } \\
\hline No, never & 180 & 35.7 \\
\hline Yes, once or twice & 180 & 35.7 \\
\hline Yes, several times & 144 & 28.6 \\
\hline \multicolumn{3}{|c|}{ Type of violence ${ }^{a}$} \\
\hline Verbal threat/Aggression & 237 & 47.0 \\
\hline Unpleasant experience & 105 & 20.8 \\
\hline Pushing & 103 & 20.4 \\
\hline Slapping/Hitting & 77 & 15.3 \\
\hline Scratching/Pinching & 41 & 8.1 \\
\hline Kicking & 32 & 6.3 \\
\hline Punching & 31 & 6.2 \\
\hline Biting & 26 & 5.2 \\
\hline Spitting & 15 & 3.0 \\
\hline Restraining & 11 & 2.2 \\
\hline Other & 28 & 5.6 \\
\hline Use of object & 54 & 16.7 \\
\hline \multicolumn{3}{|l|}{ Perpetrator } \\
\hline Passenger & 260 & 51.6 \\
\hline Co-worker (Conductor) & 91 & 18.1 \\
\hline Owner of vehicle/Company & 57 & 11.3 \\
\hline Co-worker (Driver) & 44 & 8.7 \\
\hline Stranger & 23 & 4.6 \\
\hline Police & 13 & 2.6 \\
\hline \multicolumn{3}{|l|}{ Place of occurrence } \\
\hline Bus stop & 230 & 45.6 \\
\hline While in motion & 113 & 22.4 \\
\hline Inside of vehicle & 23 & 4.6 \\
\hline Company office & 22 & 4.4 \\
\hline In the street & 19 & 3.8 \\
\hline Vehicle park & 15 & 3.0 \\
\hline Taxi stop & 14 & 2.8 \\
\hline Company garage & 12 & 2.4 \\
\hline \multicolumn{3}{|l|}{ Time of occurrence } \\
\hline Morning & 217 & 43.1 \\
\hline Evening & 194 & 38.5 \\
\hline Afternoon & 168 & 33.3 \\
\hline Dawn & 11 & 2.2 \\
\hline
\end{tabular}

${ }^{a}$ As participants may have experienced several forms of violence, proportions need not add up to $100 \%$ 
PROPORTION OF PARTICIPANTS EXPOSED TO WORKPLACE VIOLENCE DURING THE PAST 12 MONTHS BY SOCIO-DEMOGRAPHIC CHARACTERISTICS AND EMPOWERMENT INDICATORS

As shown in Table 2 below, occupational category and literacy level were associated with exposure to violence during the past 12 months. Exposure to violence was highest among bus drivers/conductors (70-75\%) even though taxi drivers (48.6\%) reported significant abuse. In addition, illiterate participants reported higher exposure (73.8\%) than their literate peers $(61.1 \%)$. The association between workplace violence in the road passenger transport sector and level of literacy and occupation reached statistical significance $(p<$ 0.05) using a chi-square test. There was no statistically significant association between exposure to workplace violence and other studied socio-demographic variables.

Table 2. Proportion of participants exposed to workplace violence during the past 12 months by socio-demographic characteristics, access to information and literacy level

\begin{tabular}{|l|c|c|c|}
\hline \multicolumn{1}{|c|}{ Variable } & $\begin{array}{c}\text { Total } \\
\text { Number }\end{array}$ & $\begin{array}{c}\text { Number } \\
\text { Exposed }\end{array}$ & Proportion \% \\
\hline Age & & & \\
\hline$<20$ yrs & 191 & 63 & 64.9 \\
\hline $20-29$ yrs & 121 & 125 & 64.4 \\
\hline $30-39$ yrs & 51 & 26 & 66.1 \\
\hline $40-49$ yrs & 33 & 24 & 51.0 \\
\hline $50-59$ yrs & 11 & 6 & 54.7 \\
\hline$>60$ yrs & & & \\
\hline Marital status & 147 & 93 & 63.3 \\
\hline Single & 292 & 184 & 63.0 \\
\hline Married/Cohabiting & 44 & 32 & 72.7 \\
\hline Divorced/Separated & 21 & 15 & 71.1 \\
\hline Widowed & & & \\
\hline Education & 116 & 83 & 71.6 \\
\hline <Primary School & 236 & 156 & 66.1 \\
\hline Primary School/Similar & 152 & 85 & 55.9 \\
\hline Upper Secondary School/University & & & \\
\hline Occupation & 72 & 51 & 70.8 \\
\hline Bus driver & 72 & 54 & 75.0 \\
\hline Bus conductor & 144 & 89 & 61.8 \\
\hline Minibus driver & 144 & 95 & 66.0 \\
\hline Minibus conductor & 72 & 35 & 48.6 \\
\hline Taxi driver & & & \\
\hline Access to information & & & 56.3 \\
\hline Have radio & 48 & 27 & 65.1 \\
\hline No & 456 & 297 & \\
\hline Yes & & & \\
\hline
\end{tabular}




\begin{tabular}{|l|c|c|c|}
\hline Have TV & & & \\
\hline No & 130 & 90 & 62.2 \\
\hline Yes & 374 & 234 & 62.6 \\
\hline Literacy level & & & \\
\hline Cannot read & 126 & 93 & 73.8 \\
\hline Can read & 378 & 231 & 61.1 \\
\hline
\end{tabular}

${ }^{*} \mathrm{p}<0.05$

PROPORTION OF PARTICIPANTS EXPOSED TO WORKPLACE VIOLENCE DURING THE PAST 12 MONTHS BY OCCUPATIONAL EXPERIENCE AND ORGANISATIONAL CHANGES

As shown in Table 3 below, a significant association was observed between workplace violence exposure in the road passenger transport sector and holding a supervisory position. A higher proportion of participants with a supervisory position had experienced abuse than colleagues without such a position $(75.7 \%$ vs. $62.3 \%)$. There was no statistically significant association between exposure to workplace violence on the one hand and occupational experience and organisational changes on the other hand.

Table 3. Proportion of participants exposed to workplace violence during the past 12 months by occupational experience and organisational changes

\begin{tabular}{|l|c|c|c|}
\hline \multicolumn{1}{|c|}{ Variable } & $\begin{array}{c}\text { Total } \\
\text { Number }\end{array}$ & $\begin{array}{c}\text { Number } \\
\text { Exposed }\end{array}$ & $\begin{array}{c}\text { Proportion } \\
\%\end{array}$ \\
\hline Occupational experience & & & \\
\hline $\begin{array}{l}\text { No. years working in road passenger } \\
\text { transport sector }\end{array}$ & & & \\
\hline $0-5$ yrs & 179 & 108 & 60.3 \\
\hline $6-10$ yrs & 206 & 136 & 66.0 \\
\hline 11-15 yrs & 86 & 55 & 64.0 \\
\hline$>15$ yrs & 33 & 25 & 75.8 \\
\hline No. years working at present workplace & & & \\
\hline $0-5$ yrs & 371 & 241 & 65.0 \\
\hline $6-10$ yrs & 115 & 71 & 61.7 \\
\hline $11-15$ yrs & 15 & 10 & 66.7 \\
\hline$>15$ yrs & 3 & 3 & 66.7 \\
\hline Hold any supervisory position ${ }^{\star}$ & & & \\
\hline No & 430 & 268 & 62.3 \\
\hline Yes & 74 & 18 & 75.7 \\
\hline Organisational changes & & & \\
\hline No & 254 & 189 & 74.4 \\
\hline Yes & 217 & 173 & 79.7 \\
\hline Don't know & 33 & 28 & 84.8 \\
\hline
\end{tabular}

${ }^{*} \mathrm{p}<0.05$ 


\section{ASSOCIATION BETWEEN EXPOSURE TO WORKPLACE VIOLENCE DURING THE PAST 12 MONTHS AND WORK ENVIRONMENT}

A significant association between exposure to workplace violence in the road passenger transport sector and work demand was found (see Table 4 below). Participants exposed to violence had a higher mean in work demand than their non-exposed peers $[t(502)=$ -4.169, $p<0.001$ ]. As high scores indicate high demands, this is an indication of higher work demands among the exposed group. There was no statistically significant association between exposure to workplace violence on the one hand and control and support at work on the other hand.

Table 4. Association between exposure to workplace violence during the past 12 months and work environment

\begin{tabular}{|l|c|c|c|}
\hline \multicolumn{1}{|c|}{ Variable } & Number & Mean & Std Deviation \\
\hline Demand (scale 5-20)* & & & \\
\hline Never exposed & 180 & 10.48 & 2.223 \\
\hline Exposed & 324 & 11.40 & 2.478 \\
\hline Control (scale 6-24) & & & \\
\hline Never exposed & 180 & 14.48 & 2.888 \\
\hline Exposed & 324 & 14.31 & 2.686 \\
\hline Support (scale 6-24) & & & \\
\hline Never exposed & 180 & 19.83 & 3.551 \\
\hline Exposed & 324 & 19.16 & 4.017 \\
\hline
\end{tabular}

${ }^{*} p<0.001$

SOCIO-DEMOGRAPHIC CHARACTERISTICS, ACCESS TO INFORMATION, LITERACY LEVEL, OCCUPATIONAL EXPERIENCE AND WORK ENVIRONMENT AS RISK FACTORS OF EXPOSURE TO WORKPLACE VIOLENCE

In the logistic regression model (adjusted odds ratios $(\mathrm{OR})$ bus conductors $(\mathrm{OR}=3.542, p$ $<0.05)$ and bus drivers $(\mathrm{OR}=3.536, p<0.05)$ exhibited a higher risk of workplace violence than taxi drivers (see Table 5 below). Literate participants $(\mathrm{OR}=0.440, p<0.05$ ) exhibited a lower likelihood of exposure to violence than their illiterate peers. Similarly, participants with $0-5$ yrs of work in the transport sector $(\mathrm{OR}=0.295, p<0.05)$ were at lower risk of exposure to workplace violence than their peers with over 15 years' experience. Participants in supervisory positions (OR $=4.044, p<0.001$ ) stood at higher risk of exposure to workplace violence than their peers without supervisory rolls. Finally, participants with higher work demand reported a higher likelihood of exposure than those with lower demands (OR = $1.230, p<0.001)$. 
Table 5. Logistic regression analysis of exposure to workplace violence during the past 12 months: Odds ratios assessing the independent role of socio-demographic characteristics, access to information, literacy level, occupational experience and work environment

\begin{tabular}{|l|c|c|c|}
\hline \multicolumn{1}{|c|}{ Variable } & $\begin{array}{c}\text { Odds ratio } \\
\text { (OR) }\end{array}$ & $\begin{array}{c}\text { 95.0\% Cl } \\
\text { of OR }\end{array}$ & p-Value \\
\hline Age & & & \\
\hline$<20$ yrs & 0.932 & $0.257-5.195$ & 0.935 \\
\hline $20-29$ yrs & 1.059 & $0.355-5.329$ & 0.949 \\
\hline $30-39$ yrs & 1.296 & $0.431-6.139$ & 0.722 \\
\hline $40-49$ yrs & 0.618 & $0.251-3.926$ & 0.518 \\
\hline $50-59$ yrs & 2.370 & $0.598-11.308$ & 0.271 \\
\hline >60 yrs & 1.000 & & \\
\hline Marital status & & & \\
\hline Single & 0.706 & $0.215-2.334$ & 0.571 \\
\hline Married/Cohabiting & 0.695 & $0.231-2.089$ & 0.517 \\
\hline Divorced/Separated & 1.323 & $0.366-4.784$ & 0.670 \\
\hline Widowed & 1.000 & & \\
\hline Education & & & 0.663 \\
\hline < Primary School & 0.822 & $0.340-1.985$ & 0.447 \\
\hline Primary School/Similar & 1.216 & $0.375-2.013$ & \\
\hline Upper Secondary School/University & 1.000 & & \\
\hline Occupation* & & & \\
\hline Bus driver & 3.536 & $1.512-8.271$ & 0.004 \\
\hline Bus conductor & 3.542 & $1.246-10.068$ & 0.018 \\
\hline Minibus driver & 1.992 & $0.879-4.516$ & 0.099 \\
\hline Minibus conductor & 1.814 & $0.645-5.102$ & 0.259 \\
\hline Taxi driver & 1.000 & & \\
\hline Access to information & & & \\
\hline Have radio & & & 0.032 \\
\hline No & 1.000 & & \\
\hline Yes & 1.463 & $0.745-2.871$ & \\
\hline Have TV & & & \\
\hline No & 1.000 & & \\
\hline Yes & 1.225 & $0.703-2.135$ & \\
\hline Literacy level & & & \\
\hline Cannot read fully/Cannot read & 1.000 & & \\
\hline Can read fully & 0.440 & $0.207-0.934$ & \\
\hline Occupational experience & & & \\
\hline No. years working passenger transport sector & & & \\
\hline & & & \\
\hline & & & \\
\hline
\end{tabular}




\begin{tabular}{|l|l|l|l|}
\hline $0-5$ yrs & 0.295 & $0.093-0.931$ & 0.037 \\
\hline $6-10$ yrs & 0.417 & $0.141-1.232$ & 0.113 \\
\hline $11-15$ yrs & 0.488 & $0.170-1.403$ & 0.183 \\
\hline$>15$ yrs & 1.000 & & \\
\hline $\begin{array}{l}\text { No. years working at present } \\
\text { workplace }\end{array}$ & & & \\
\hline $0-5$ yrs & 1.189 & $0.076-18.635$ & 0.902 \\
\hline $6-10$ yrs & 0.701 & $0.045-11.003$ & 0.800 \\
\hline $11-15$ yrs & 0.950 & $0.051-17.752$ & 0.972 \\
\hline$>15$ yrs & 1.000 & & \\
\hline Hold any supervisory position & & & \\
\hline No & 1.000 & & 0.000 \\
\hline Yes & 4.044 & $2.028-8.066$ & \\
\hline Work environment ${ }^{*}$ & & & 0.000 \\
\hline Demand & 1.230 & $1.118-1.354$ & 0.469 \\
\hline Control & 0.970 & $0.892-1.054$ & 0.078 \\
\hline Support & 0.950 & $0.898-1.006$ & \\
\hline
\end{tabular}

\section{DISCUSSION}

The aims of this cross-sectional survey were to analyse the extent and nature of workplace violence against drivers and conductors and to identify the individual and work-related factors related to being abused as a worker in the road passenger transport sector in Maputo. The findings indicated that victimisation (both verbal and physical) at work was common, occurring virtually everywhere including on the road while the vehicle was in motion; inside the vehicle or company office; in the street, vehicle park or company garage; and at the bus/taxi stop. The life time prevalence was $77 \%$. Though comparable data from the transport sector with regard to lifetime prevalence is lacking, the current figures seem comparable with studies among healthcare employees where a prevalence ranging between $71-85 \%$ has been reported (Lawoko et al., 2004; Soares et al., 2000). Two out of three respondents had been abused during the past 12 months. These figures are comparable with previous work from other countries where a prevalence of between 6074\% has been reported (Boyd, 2002; Chappell \& Di Martino, 2006; Elzinga, 1996; Mayhew, 2000). The high prevalence of violence in the road passenger transport sector in the current and previous studies is an indication that employment in this sector is associated with high vulnerability for abuse. Identification of groups most at risk is, therefore, paramount in the prevention of violence in the sector. In this study, individual and work-related factors were investigated to identify possible risk groups in this regard.

Individual characteristic, such as age, education and marital status, did not impact significantly on the likelihood of exposure to workplace violence. These findings are rather difficult to reconcile considering that a young age has previously been implicated as a 
potential risk factor in the health sector (Arnetz et al., 1996; Duncan et al., 2001; Fazzone et al., 2000; Lawoko et al., 2004; Lee et al., 1999; Menckel \& Viitasara, 2002; Soares et al., 2000). Moreover, the ecological model of violence (Krug, Dahlberg, Mercy, Zwi, \& Lozano, 2002), has indicated that factors at the individual level, such as less schooling and young age, may be associated with increased vulnerability to abuse. On the other hand, illiteracy was associated with increased vulnerability as postulated in the ecological model framework. These inconsistencies warrant further research. As studies in this sector are scarce in general and lacking in the African context, replication of these findings in similar settings is warranted before any firm conclusions can be drawn in this regard.

Some work-related factors impacted significantly on the likelihood of exposure to workplace violence in the expected manner while others did not. Short occupational experience (0-5 years) reduced the likelihood of abuse when contrasted with over 15 years' experience. This finding is contradictory to other studies which have suggested increased exposure among inexperienced personnel (Arnetz \& Arnetz, 2000; Arnetz et al., 1996; Fazzone et al., 2000; Lawoko et al., 2004; Soares et al., 2000). The differences in findings could be contextual (e.g. differences in sectors investigated). It would have been expected that experienced personnel would be more able to predict and diffuse situations in which violence is expected to occur than their inexperienced peers. On the other hand, conductors and drivers tend to meet a very heterogeneous clientele. The likelihood of being able to predict and diffuse a potentially violent situation thus may be small and, therefore, independent of experience. Another plausible explanation could be that more experienced personnel hold a supervisory role, by virtue of their experience, while those with a supervisory role are more vulnerable to assaults. Supervisors are often at the forefront of service in this branch. They may be called upon to resolve difficult conflicts between other employees and passengers. This may prompt assertive action from either party in the conflict, increasing the likelihood of aggression, whether planned or spontaneous, by colleagues or passengers. This finding is in line with those reported among healthcare employees (Arnetz et al., 1996; Menckel \& Viitasara, 2002). Furthermore, supervisors' other duties, such as checking that all vehicles have a valid licence; inspecting that vehicles have undergone the yearly service; and ensuring that vehicles follow the order of arrival at the stations (e.g. taxi stop and bus/mini buses terminals) may increase the likelihood of internally induced aggression against employees not meeting such demands. All in all, the findings with regard to higher vulnerability to abuse among experienced personnel and those with a supervisory role warrant further investigation and research.

Work characteristics, such as work demand (high demand), occupation and a supervisory position, were significantly associated with exposure to abuse. Exposure was highest among bus drivers and bus conductors, though taxi drivers also suffered significant abuse. The latter finding is in line with previous reports (Castillo \& Jenkins, 1994; Elzinga, 1996; 
Essenberg, 2003; Jenkins, 1996; Mayhew, 2000; Richardson \& Windau, 2003). Comparative data with regard to drivers and conductors' exposure to violence is lacking. That taxi drivers experienced less abuse than bus drivers and conductors in the Mozambican context could be explained by differences in environmental characteristics. Buses tend to be overcrowded and this is likely to increase stress stimuli, thus increasing the risk of an aggressive encounter. Taxi transport tends to be more organised. Another plausible explanation could be found in the differences in clientele. Taxi users tend to be of middle class status, more educated and in general hold a higher status in society than their peers using bus transport. Theories of violence (ecological theory) have suggested that perpetrators of violence are more likely to belong to the lower socio-economic strata (Krug et al., 2002). The risk of violence may thus be higher among bus passengers who tend to belong to the lower socioeconomic strata. Further analysis of socio-economic differences in passengers' choices of transport mode is warranted to support this argument.

High work demand was associated with increased vulnerability to abuse. These findings are consistent with studies in the health sector (Estryn-Behar et al., 2008; Menckel \& Viitasara, 2002), and could be explained based on theories which have purported that high demands with low control may affect quality delivery (Karasek \& Theorell, 1990). Drivers and conductors with these characteristics may, therefore, fail to meet passenger expectations, thus increasing the risk of aggression. Indeed, a recent study in the transport sector apparently supported this notion (Boyd, 2002). Though passengers were the most common perpetrators, violence perpetrated by a work colleague appeared rather common (over 20\%). These findings corroborate others in the field which have suggested that significant workplace violence is internally triggered (Chappell \& Di Martino, 2006; Essenberg, 2003; ILO, 2004). Working under conditions of high demand is likely to elicit stress stimuli, thus increasing the risk of confrontation even among co-workers. Indeed, the results suggested high work demand in general. Improvement of the working conditions in this sector is, therefore, paramount in the prevention of workplace violence.

The strength of this study lies in its careful methodology. The sample size was determined using a power analysis and all participants responded to the questionnaire. The results can, therefore, be generalised to employees working in this sector in Maputo. That all eligible participants responded (100\%), though ideal, is unusual. A number of factors acting together may have accounted for this total response. For example, it is plausible that participants may have found the topic highly relevant. Another explanation for the total response could stem from the project organisation. Information dissemination regarding the study and its objectives, training of data collection personnel, emphasis on ethical considerations such as privacy and confidentiality guarantee may have contributed to the total response rate. The incentive package offered to participants is another factor that may constitute a major contributor to the total response rate (i.e. all participants needing psychological support 
or medical care due to hearing, vision and sleep problems were referred to government hospitals, where treatment is free of charge). These factors notwithstanding, the possibility of participants being coerced to participate in the study cannot be ruled out entirely. It is plausible that their employers may have signalled participation as an obligation when informing participants of the study.

The weaknesses of the study, however, stemed from the design. The study design was cross-sectional making it difficult to draw causal conclusions. For example, while it is likely that a high workload may increase exposure to violence, reporting a high workload could as well be a result of victimisation, i.e. victims of violence may find their work demanding as a result of victimisation at work. Studies with a longitudinal design are necessary in order to establish firm causal links. The study did not investigate the context of the situation that might have led to the act of aggression. This would have been useful in identifying contextual factors (e.g. overcrowding, lateness of driver, evading payments of fares) that trigger acts of aggression, important in prevention of workplace violence. Future work needs to address this limitation.

Finally, the study has some implications for intervention to prevent and combat workplace violence in the road passenger transport sector. Firstly, a strategy for identifying the occurrence of workplace violence should consider that workplace violence is highly prevalent and occurs everywhere in this sector including while on the road. Employees should, therefore, be supported through a guarantee of their security at all times during their work. This could be accomplished by regular check points by security personnel hired by the unions or the improvement of communications with such personnel while on duty. Secondly, the improvement of work conditions is paramount. Among other things, development of a guide for employers and employees on how to detect and control workplace violence is needed. Moreover, research concerning workplace violence risk factors particularly from the perpetrator's perspective will be complementary in understanding the holistic view of the mechanism of work place violence in the road passenger transport sector.

\section{CONCLUSIONS}

Workplace violence in the road passenger transport sector is common and occurs wherever personnel are on duty, with bus drivers and conductors being at increased risk when compared with taxi drivers. Work-related factors including high demands and holding an authoritative position increase the likelihood of being victimised in this sector. Work-related factors thus have important implications for interventions to reduce workplace violence in this sector. The role of individual related factors in exposure to workplace violence is inconsistently demonstrated suggesting that further research is warranted. This study should set the pace for further work in the area in other sub-Saharan African contexts. Finally, longitudinal studies are recommended to confirm causal links. 


\section{REFERENCES}

Arnetz, J.E. (1998). The Violent Incident Form (VIF): A practical instrument for the registration of violent incidents in the health care workplace. Work \& Stress, 12(1), 17-28.

Arnetz, J.E., \& Arnetz, B.B. (2000). Implementation and evaluation of a practical intervention programme for dealing with violence towards health care workers. Journal of Advanced Nursing, 31(3), 668-680.

Arnetz, J.E., \& Arnetz, B.B. (2001). Violence towards health care staff and possible effects in the quality of patient care. Social Science \& Medicine, 52(3), 417-427.

Arnetz, J.E., Arnetz, B.B., \& Petterson, I.L. (1996). Violence in the nursing profession: Occupational and life style risk factors in Swedish nurses. Work \& Stress, 10(2), 119-127.

Boyd, C. (2002). Customer violence and employee health and safety. Work, Employment and Society, 16(1), 151-169.

Boothby, N. (1992). Displaced children: Psychological theory and practice from the field. Journal of Refugee Studies, 5(2), 106-122.

Bureau of Justice Statistics (BJS). (2007). National Crime Victimization Survey in 2005. Washington, DC.

Bureau of Labor Statistics (BLS). (2007). National census of fatal occupational injuries in 2005. Washington, DC.

Carmi-lluz, T., Peleg, R., Freud, T., \& Shvartzman, P. (2005). Verbal and physical violence towards hospital and community-based physicians in the Negev: An observational study. BMC Health Services Research, 5(54), 54.

Castillo, D., \& Jenkins, L. (1994). Industries and occupations at high risk for work-related homicide. Journal of Occupational Medicine, 36(2), 125-132.

Chappel, D., \& Di Martino, V. (2006). Violence at work. Geneva: ILO.

Di Martino, V. (2002). Workplace violence in the health sector-Country case studies: Brazil, Bulgaria, Lebanon, Portugal, South Africa, Thailand, plus an additional Australian study: Synthesis report (p. 42). Geneva: International Labour Office (ILO)/International Council of Nurses (ICN)/World Health Organization (WHO)/ Public Services International (PSI).

Di Martino, V. (2003). Workplace violence in the health sector: Relationship between work stress and workplace violence in the health sector. Geneva: ILO/ICN/WHO/PSI.

Duncan , S.M., Kathryin H., Carole A., Estatbrooks et al.(2001). Nurses experiences of violence in Alberta and British Columbia Hospitals. Canadian Journal of Nursing Research, 32(4), 57-78.

Eduardo Mondlane University. (2003). Violence against health personal in some health care units in Maputo city. Geneva: ILO/ICN/WHO/PSI.

Elzinga, A. (1996). Security of taxi drivers in the Netherlands: Fear of crime, actual victimization and recommended security measures. Security Journal, 7(3), 205-210.

Essenberg, B. (2003). Violence and stress at work in the transport sector. Geneva: ILO.

Estryn-Behar, M., B. van der Heijden, et al. (2008). "Violence risks in nursing--results from the European 'NEXT' Study." Occupational Medicine, 58(2), 107-14. 
European Foundation for the Improvement of Living and Working Conditions. (2007). Fourth European Working Conditions Survey. Luxemburg.

Fazzone, P.A., Barloon, L.F., MacConnell, S.J., \& Chitty, J.A. (2000). Personal safety, violence and home health. Public Health Nursing, 17(1), 43-52.

Hirsch, B.J. (1980). Natural support systems and coping with major life changes. American Journal of Community Psychology, 8, 159-172.

House, J.S. (1985). Work stress and social support. Reading, MA: Addison-Wesley.

Instituto Nacional de Estatística (National Statistics Institute [INE]). (2002). Dados sócio demograficos (Sociodemographic data). Maputo: Author.

Instituto Nacional de Estatística (INE). (2005). Dados sócio demográficos (Socio-demographic data). Maputo: Author.

Instituto Nacional de Estatística (INE). (2007). Resultados Preliminares do 3ㅜ. recenseamento geral da população e habitação (Preliminary results of 3rd general population and housing census). Maputo: Author.

International Labor Office (ILO). (2004). Workplace violence in services sectors and measures to combat this phenomenon. Geneva: Author.

Jackson, M., \& Ashley, D. (2005). Physical and psychological violence in Jamaica's health sector. Revista Panamericana de Salud Publica, 18(2), 114-121.

Jenkins, E.L. (1996). Workplace homicides: Industries and occupations at high risk. Journal of Occupational Medicine, 11(2), 219-225.

Johnson, J.V., \& Hall, E.M. (1988). Job strain, work place support, and cardiovascular disease: A crosssectional study of a random sample of the Swedish working population. American Journal of Public Health, 78, 1336-1342.

Johnson, J.V., Hall, E.M., \& Theorell, T. (1989). Combined effects of job strain and social isolation on cardiovascular disease morbidity and mortality in a random sample of the Swedish male working population. Scandinavian Journal of Work Environment \& Health 15(4), 271-279.

Karasek, R.A. (1979). Job demands, job decision latitude, and mental strain: Implications for job redesign. Administrative Science Quarterly, 24, 285-307.

Karasek, R.A., \& Theorell, T. (1990). Healthy work: Stress, productivity, and the reconstruction of working life. New York: Basic Books.

Kasara, S., Pathrapon, T., \& Bungorn, S. (2003). Workplace violence in the health sector. A cause study in Thailand (p. 35). Geneva: ILO/ICN/WHO/PSI.

Kowalenko, T., Walters, B.L., Khare, R.K., \& Compton, S., with the Michigan College of Emergency Physicians Workplace Violence Task Force. (2005). Workplace violence: A survey of emergency physicians in the state of Michigan. Annals of Emergency Medicine, 46(2), 142-147.

Krug, E.G., Dahlberg, L.L., Mercy, J.A., Zwi, A.B., \& Lozano, R. (2002). World report on violence and health. Geneva: WHO.

Kwok, R.P., Law, Y.K., Li, K.E., Ng, Y.C., Cheung, M.H., Fung, V.K., Kwok, K.T., et al. (2006). Prevalence of workplace violence against nurses in Hong Kong. Hong Kong Medical Journal, 12(1), 6-9. 
Lanza, M.L., Zeiss, R., \& Rierdan, J. (2006). Violence against psychiatric nurses: Sensitive research as science and intervention. Contemporary Nurse, 21(1), 71-84.

Lawoko, S., Soares, J.J.F., \& Nolan, P. (2004). Violence towards psychiatric staff: A comparison of gender, job and environmental characteristics in England and Sweden. Work \& Stress, 18(1), 39-55.

Lee, S.S., Gerberich, S.G., Waller, L.A., Anderson, A., \& MacGovern, P. (1999). Work-related assault injuries among nurses. Epidemiology, 10(6), 685-691.

Lundström, M., Saveman, B.I., Eissemann, M., \& Astöm, S. (2007). Prevalence of violence and its relation to caregivers' demographics and emotional reactions: An explorative study of caregivers working in group for persons of learning disabilities. Scandinavian Journal of Caring Sciences, 21(1), 84-90.

Mayhew, C. (2000). Violent assaults on taxi drivers: incidence patterns and risk factors. Trends and Issues in Crime and Criminal Justice, 178.

Menckel, E., \& Viitasara, E. (2002). Threats and violence in Swedish care welfare - magnitude of the problem and impact on municipal personnel. Scandinavian Journal of Caring Sciences, 16(4), 376-385.

National Institute for Occupational Safety and Health (NIOSH). (2007). Workplace homicides in the United States. Washington, DC.

Nizamo, H., Meyrowitsch, D.W., Zacarias, E., \& Konradsen, F. (2006). Mortality due to injuries in Maputo City, Mozambique. International Journal of Injury Control and Safety Promotion, 13(1), 1-6.

Nolan, P., Soares, J.J.F., Dallender, J., Thomsen, S., \& Arnetz, B. (2001). A comparative study of the experiences of violence of English and Swedish mental health nurses. International Journal of Nursing Studies, 38(4), 419-426.

Norbeck, J.S., Lindsey, A.M., \& Carrieri, V.L. (1981). The development of an instrument to measure social support. Nurse Resident, 30, 263-269.

Palacios, M., Loureiro dos Santos, M., Barros do Val, M., Medina, M.I., de Abreu, M., Soares, J.J.F. et al. (2003). Workplace violence in the health sector. Country case study - Brazil (p. 66). Geneva: ILO/ICN/WHO/ PSI.

Richardson, S., \& Windau, J. (2003). Fatal and non fatal assaults in the workplace 1996-2000. Clinics in Occupational and Environmental Medicine, 3(4), 673-689.

Schat, A.C.H., \& Kelloway, E.K. (2005). Workplace aggression. In J. Barling, E.K. Kelloway \& M.R. Frone (Eds.). Handbook of work stress (pp. 189-218). Thousand Oaks, CA: Sage.

Soares, J.J.F., Lawoko, S., \& Nolan, P. (2000). The nature, extent and determinants of violence against psychiatric personnel. Work \& Stress, 2, 105-120.

Steinman, S. (2003). Workplace violence in the health sector. Country case study - South Africa (p. 59). Geneva: ILO/ICN/WHO/PSI.

Viitasara, E., Sverke, M., \& Menckel, E. (2000). Multiple risk factors for violence to seven occupational groups in the Swedish caring sector. Industrial Relations, 85, 20.

Winstanley, S., \& Whittington, R. (2002). Anxiety, burnout and coping styles in general hospital staff exposed to workplace aggression: a cyclical model of burnout and vulnerability to aggression. Work \& Stress, 16(4), 305-315. 